IZA DP No. 9018

Are China's Ethnic Minorities Less Likely to Move?

Björn Gustafsson

Xiuna Yang

April 2015

Forschungsinstitut zur Zukunft der Arbeit Institute for the Study of Labor 


\title{
Are China's Ethnic Minorities Less Likely to Move?
}

\author{
Björn Gustafsson \\ University of Gothenburg \\ and IZA \\ Xiuna Yang \\ Beijing Normal University
}

\section{Discussion Paper No. 9018 \\ April 2015}

\author{
IZA \\ P.O. Box 7240 \\ 53072 Bonn \\ Germany \\ Phone: +49-228-3894-0 \\ Fax: +49-228-3894-180 \\ E-mail: iza@iza.org
}

\begin{abstract}
Any opinions expressed here are those of the author(s) and not those of IZA. Research published in this series may include views on policy, but the institute itself takes no institutional policy positions. The IZA research network is committed to the IZA Guiding Principles of Research Integrity.

The Institute for the Study of Labor (IZA) in Bonn is a local and virtual international research center and a place of communication between science, politics and business. IZA is an independent nonprofit organization supported by Deutsche Post Foundation. The center is associated with the University of Bonn and offers a stimulating research environment through its international network, workshops and conferences, data service, project support, research visits and doctoral program. IZA engages in (i) original and internationally competitive research in all fields of labor economics, (ii) development of policy concepts, and (iii) dissemination of research results and concepts to the interested public.
\end{abstract}

IZA Discussion Papers often represent preliminary work and are circulated to encourage discussion. Citation of such a paper should account for its provisional character. A revised version may be available directly from the author. 
IZA Discussion Paper No. 9018

April 2015

\section{ABSTRACT}

\section{Are China's Ethnic Minorities Less Likely to Move?*}

This study uses China's Inter-Census Survey 2005 to analyse the extent migration behaviour among 14 large ethnic minority groups and the Han majority. Results show that the probability to migrate to all types of destinations varies by province of origin, decreases by age, and in most cases, by expected income at the origin. Furthermore the probability to migrate is found to typically increase by length of education and decrease for females by the number of children. In most cases investigated, a minority ethnicity reduces migration probabilities for people registered in rural China. This is particularly the case for persons belonging to the Uyghur and Tibetan ethnic groups, but also for the Mongolian, Bai, Yao and Tujia groups. In contrast, Korean and Hui have a higher probability of migration than the majority. For people with an urban hukou there are fewer examples that minority ethnicity affects probability to migrate.

JEL Classification: J15, J61, J7, P23

Keywords: China, ethnic minorities, Uighur, Tibetan, Korean, Hui

Corresponding author:

Björn Gustafsson

Department of Social Work

University of Gothenburg

P.O. Box 720

SE 40530 Göteborg

Sweden

E-mail: Bjorn.Gustafsson@socwork.gu.se

\footnotetext{
* Much of Xiuna Yang's work was carried out when she was a visiting PhD student at the University of Gothenburg funded by a grant from the China State Scholarship Council (CSC).
} 


\section{Are China's Ethnic Minorities Less Likely to Move?}

\section{Introduction}

Migration is one of contemporary China's largest issues with many dimensions and consequences. Some moves occur within counties and cities. Other moves have a destination, rural or urban, within the same province or in another province. Particularly visible and important is the extensive flow of young adults with a rural hukou who have moved to a city with the hope of attaining a higher living standard. This rural to urban migration raises questions on how the population composition changes, how migrants fare at the destination as well as on how the moves affect those they left behind. Related to this at the policy level are issues on reform of the hukou system and public policies that aim to integrate rural and urban areas, thereby lessening migration pressure. See for example Yao et al. (2004), Zhang et al. (2008), Cai (2011), Shi (2012), and Sun et al. (2011).

There is now a large body of literature on contemporary migration in China. Different research questions relating to different migration-flows have been asked and various research methods applied. See for example Zai (2001), Ma (2001), Zhao (2002), Knight and Song (2005, Zhong (2006), Shen (2011), Cheng (2006), Li (2003) and Fan (2008). However, despite their making up more than 110 million persons, little research has focused on geographical mobility among China's ethnic minorities and how it compares to movement among the ethnic majority. True, there are studies of particular ethnic minorities, and origins or destinations. ${ }^{1}$ However, we are not aware of any previous attempts to research the big picture by analysing China as a whole along with many minority groups. This article aims to fill this gap in knowledge on ethnic minority migration in China by focusing on movement out of the cities and counties, and study people who grew up in rural as well as urban locations and who now live elsewhere.

To be specific, we are first interested in knowing how large a proportion of persons belonging to the Han majority and each of China's 14 largest ethnic minorities had migrated in 2005. Our main research question is whether a person belonging to a specific ethnic minority has a different and lower probability to migrate than a majority person, when allowing for personal 
characteristics such as age, gender, education, marital status, health status, province and potential income at the origin.

Does it matter if a particular ethnic minority migrates to a lesser extent than the majority or has a lower probability of migrating? One set of concerns relates to the positive sides of economic development. One can claim that in the present Chinese context, rural to urban migration is an important mechanism fostering the country's rapid economic development. After migration, low-productive peasants typically change into high-productive workers in industry or construction, for example. It is difficult to imagine China's rapid industrialization in the cities without the existence of a large stream of migrants. Furthermore, migration can also benefit growth in rural China via different channels. For example, upon returning to their origins, migrants can have acquired new skills and thereby have become more productive. Such a description is appropriate for some migrants, but not for all. Another channel is open when income earned by the migrant is sent or brought back to those left behind. These remittances can increase consumption or be used for productive purposes thus increasing productivity. ${ }^{2}$

In cases where ethnic minorities do not take part in migration to the same extent as the majority, there are not only consequences for the distribution of the populations across space. It also means that economic growth among the ethnic minorities is at risk of lagging behind that of the majority. This can be viewed as problematic from a social justice point of view and also risks breeding social tensions. However, for a minority, a high propensity to migrate can make their numbers at the origin decrease in a manner that causes the special status of ethnic area to be at risk of being questioned. Paik and Ham (2012) discuss this with respect to migration by the Korean minority.

This study uses a subsample of China's Inter-Census Survey 2005. We define a migrant as a person who at the time of the survey has lived in another city/county than where he/she is registered for at least half a year. Individuals studied are adults under age 60 who are not students. Migrants defined in this way are estimated to number 91 million persons, see Table 3. Among these, 49 percent have moved from a rural to an urban location, 23 percent from a rural to another rural location, 23 percent from an urban to another urban location and only 5 percent 
from an urban location to a rural location, see Table 4. We find that among the Han ethnic majority, 11.9 percent have migrated and such migration rates are lower among almost all of the 14 ethnic minority groups studied.

In order to better understand whether minority ethnicity is a barrier to migration, we estimate multinomial logit models. For people with a rural hukou we specify four types of movement depending on destination: urban within the same province, urban between province, rural within the same province, and rural between province. Explanatory variables measure ethnicity, family circumstances, age, education, health, income opportunity at place of origin and province of origin. Similar models are also specified and estimated for the population registered with an urban hukou.

As preview, our results confirm that the probability for all types of migration decreases by age, decreases in most cases by expected income at the origin, and decreases for females by the number of children. Furthermore, the probability of migrating increases in most cases by length of education while health status can play a role as well. Province at origin also matters. A major result is that in most cases, minority ethnicity reduces migration probabilities for people registered in rural China. This is particularly the case for persons who belong to the Uyghur and Tibetan ethnic groups, but also for the Mongolian, Bai, Yao and Tujia groups. In contrast,

Korean and Hui have a higher probability to move than the Han. For people who are registered in urban areas the relationship between ethnicity and probability to migrate is to a large extent different. Examples of ethnicity being related to migration to another urban area are few. The major exception is that in the small stream of migrants from urban to rural areas, ethnic minority status is found to augment the probability to migrate in several cases.

\section{Ethnic Minority Migration in China}

There are several reasons why we can expect that a rural ethnic minority persons with the same characteristics as a Han person is less likely to move. Ethnicity can affect whether or not a person finds a job at a new destination, the kind of job he or she finds upon arrival, the possibilities for making a career, and possibly even the earnings for a given job. One group of 
factors contributing to this are characteristics of the potential migrant. An ethnic minority person can have a low command of the language used at the potential destination. Another and often interrelated reason is that lack of access to networks which can make it difficult to find a job, housing and consumers (for those who are self-employed, for example). Ethnic differences in access to network may in turn originate from previous immigration streams. A clear example is Xinjiang where a strikingly large proportion of Han inhabitants themselves or their ancestors have migrated to the region, for example see Ren and Yuan (2003). As a consequence many Han in Xinjiang different from ethnic minority persons can be supposed to have useful connections outside the region.

Another group of factors why ethnic minority persons are less likely to move than a Han person with the same age, education, marital status and health refers to those who are employ workers, who are potential customers as well as those who rent or sell housing. Ethnic minority persons can be discriminated in one or several of the various markets. Discrimination in the labour market can be due to preferences or whether minority persons are perceived to be less productive on average than majority persons. There is now convincing evidence on the existence of ethnic discrimination in hiring practices in China. Maurer-Fazio (2012) conducted a largescale field experiment to investigate how Chinese firms respond to job board applications from Mongolian, Tibetan, and Uyghur as well as Han applicants. Results showed lower call-back rates for all three minorities investigated. ${ }^{3}$

Still another possible reason applies to certain ethnic minorities and movement from rural to urban areas. Here we refer to minorities where "traditional" gender roles are more prevalent than in urban areas where most mothers work outside the home. ${ }^{4}$ Finally, another reason for why ethnic minorities are not as likely to move pertains to the extent that ethnic minority persons positively value membership in an ethnic community and consumption of ethnic goods and services. With such considerations, the alternative of leaving the home village with many residents of the same ethnicity for a city appears less attractive.

Urban life in China differs from rural life in many respects. Rural people live in villages which are often segregated by ethnicity. As a consequence in daily life, rural people typically interact 
predominately with people of the same ethnicity. True ethnic enclaves exist in several Chinese cities (Chen 2008). However, for the city dweller, contact with people in the workplace or as a consumer is often ethnically more diverse. For these reasons we hypothesise that while ethnicity can play a substantial role for migration that originates from rural China, the role is smaller or even non-existent for persons originating from urban China.

**Table one around here**

As the outcome of a historical and political process, contemporary China is composed of the Han Majority and 55 officially defined ethnic minorities, (See for example Kaup 2000; Mullaney 2011) of which our data makes it possible to study the 14 largest. They are listed by name and size in Table 1 which also shows their population size, concentration to province of domicile as well as their urbanization rate. The estimates of population size are derived as the average from what NBS has reported from the 2000 census and the 2010 census. The largest minority is Zhuang with 16.6 million persons followed by Manchu (10.5 million), Hui (10.2 million) and Uyghur (9.2 million). After these come Miao, Yi, Tibetan, Mongolian, Tujia, Dong, Bouyei and Yao. The smallest of the 14 are the Bai and the Korean with about 2 million people each.

In addition to size, China's ethnic minorities differ from each other in many other respects. One is area of residence. Particularly many minorities are concentrated to southwest China. This is the case for 8 of the 14 investigated: Dong, Zhuang, Tujia, Miao, Yao, Bouyei, Bai and Yi. Tibetan is concentrated to the west, Uyghur to Xinjiang autonomous region and Mongolian to Inner Mongolia autonomous region. Northeast China is the home of most persons belonging to Manchu and Korean minorities. The Hui are rather dispersed across provinces with some concentration to Ningxia autonomous region. The rate of urbanization differs considerably across the ethnic minorities as well. One extreme is the Korean ethnic minority which is more urbanised than the population of China as a whole. The proportion of Hui, Manchu and Mongolian living in cities is similar to that of the Han majority. In contrast, the rate of urbanization is lower than the average for as many as 10 of the 14 ethnic minorities studied.

** Table Two Around Here ** 
Table 2 shows length of schooling (by rural and urban locations for men and women) as well as rates of endogamy for 14 minorities and the majority. It is well-established that urban people have longer educations than rural people. The gender gap in length of education is more pronounced in rural China. Similarly we find larger ethnic differences in length of education in rural China than in urban China. The Tibetan cohort stands out as having the shortest education in rural as well as urban areas. In most cases, ethnic minorities living in rural China have shorter educations than Han people of the same gender. The major exception is the Korean with longer educations than the Han. ${ }^{5}$ In addition, the Manchu have a length of schooling similar to the Han. Table 2 also shows that most ethnic minorities (like the majority) marry within their ethnic groups. The only exception is the Manchu among whom one-half have married out of their ethnic group. The other extreme is the Uyghur among whom inter-ethnic marriages are even more uncommon than among the Han majority. It is also rather unusual for Tibetan persons to marry persons belonging to another ethnic group.

Many ethnic minority persons use their own language in daily communication and some also have their own written language. Exceptions are the Hui and Manchu who, with very few exceptions, use the same language as the majority. Regarding religion there is also large variation. For example, the Hui and Uyghur, but not the other minorities studied here, are Muslim. The large variation in many circumstances across minorities mean that it is often justified to treat each ethnic minority separately in an analysis, as is done here and not as one entity.

\section{Sample Characteristics}

** Table Three Around Here **

For this study we use a subsample . The survey took place in November 2005. It is a 1 percent sample of the current population derived by a three-stage cluster sampling method as further described by Weimin (no year). We have access to a subsample in which it is possible with some precision to study each of the 14 largest ethnic minorities. ${ }^{6}$ The sample we work with 
includes people living in rural areas (nong cun di qu) and urban areas (cheng shi di qu) in 345 cities (shi) out of China's 660 cities (shi). Of people surveyed, 13.2 percent at the time of the census were living in another location than where registered. Among these migrants, one-third had migrated within the city or county where they were registered, and two-thirds out of the city or country where they were registered. Our study deals with the latter category which makes up 8.8 percent of the total population. As we are primarily interested in work-motivated migration, we exclude from the analysis persons under 16, those who are over 60 as well as those who are students. This leaves us with 182008 observations of migrants which corresponds to a population of 91 million persons (see Table 3) and 1440874 observations of stayers. ${ }^{7}$

\section{** Table Four Around Here **}

The upper part of Table 4 shows that among the migrants studied here, 73 percent originate from a rural area and 27 percent from an urban area. Among all migrants approximately half are rural to urban migrants, while slightly less than one-quarter are urban to urban migrants and equally many rural to rural migrants. Only 5 percent are people with an urban hukou who have been living for at least half a year in a rural place at the time of the census. The lower part of Table 4 provides a more detailed view by distinguishing destinations; those within the same province and those that are in another province. With regard to such a disaggregation we can see a difference between migration from rural and urban areas. Among migrants of rural origin, destinations in other provinces dominate, while among migrants from urban origins, destinations in the same province dominate.

\section{** Figure One Around Here **}

In Figure 1 we report for each of the 14 ethnic minorities and the majority how large a percentage of the population aged 16 to 60 (not students) were migrants in 2005 by bars ordered by proportion of migrants. A rather large variation is shown - from 15.4 percent among Korean, 12.8 percent among Dong, and 11.9 among Han, down to 2.7 percent among Yi and 1.8 percent among Tibetan and Uyghur. For the more urbanized ethnic minorities, Koreans, Hui, Manchu 
and Mongolians, the percentage of urban to urban migrants is of similar size to the percentage of rural to urban migrants. In the remaining eight cases rural to urban migrants dominate in number.

** Figure Two Around Here **

Migration rates also vary by province of origin. This is shown in Figure 2 where provinces are arranged by proportion of migrants in relation to number of persons with a hukou in the province. With a migrant rate as high as 22.9 percent, Anhui is at the top followed by Sichuan with 21.8 percent and thereafter Hunan with 19.9 percent. At the other end we find Xinjiang and Shanxi with only 3.9 percent migrants while the extreme is Tibet with as few as 1.4 percent migrants. For obvious reasons the single largest subcategory of migrants originating from Shanghai, Beijing and Tianjin is that of the urban to urban migrants.

\section{Modelling Rural People's Migration}

As many of China's ethnic minorities live in provinces with a low proportion of migrants and have shorter educations than Han persons, it is not necessarily the case that ethnicity means that a minority person living in the same place and having the same length of education as a majority person has a lower probability to migrate. In order to gain a better understanding of whether ethnicity is related to migration once we have considered location and a number of personal characteristics, we specify and estimate a multinomial logit model for persons with a rural hukou. The model relates the probability of migration to different types of destinations to a number of variables that have been found to affect migration in China and elsewhere as well as a string of dummy variables indicating ethnicity. We define, in addition to the state "stayers", four destinations: An urban location in the same province, an urban location in another province, a rural location in the same province and a rural location in another province.

Explanatory variables for the datasets of people with a rural hukou are listed in Table 5 where there is also one column for people with an urban hukou (analysed in the next section). There are 14 dummy variables, one for each of the ethnic minorities studied and one for a residual category of ethnic minorities. Han is the omitted category in the specification. For men 
we distinguish between married and unmarried (the omitted category) and for women we distinguish between unmarried, married with no children, married with one child, married with two children and married with more than two children. ${ }^{8}$ There are eight dummy variables for age with aged 16 to 20 as the omitted category. There is one dummy variable for being unhealthy (healthy is the omitted category). ${ }^{9}$ There are 4 dummy variables for degree of education ("junior middle school" is the omitted category).

We aim to capture circumstances at the origin by one variable indicating expected income at the place of origin as well as 30 dummy variables of province at origin (Heilongjiang as the omitted province). Expected income at the origin is predicted based on regressions for each of the 345 cities from which data has been generated. In these equations the dependent variable is the logarithm of monthly income ${ }^{10}$. The specification included the following string of dummy variables: married male, unmarried female, married women with no child, married female with one child, married female with two children and married female with more than two children. The specification also included age (a continuous variable measured in years), age squared, dummies for level of education (for the categories "never been to school", "primary school", "senior middle school", "college and above", the omitted category is "junior middle school") and a dummy for urban Hukou (rural hukou is omitted category); dummies for health (for each of the categories: "can maintain basic living and work", "cannot live or work normally", "not clear", and "healthy" is the omitted category).

\section{** Table Five Around Here **}

Comparing descriptive statistics for persons with rural and urban hukous, some well-known differences can be seen in Table 5. Relatively few urban wives have more than one child, while this is not the case for rural wives. A larger proportion of urban people have a long education, and income at the origin is considerably higher in urban China than in rural China.

** Table Six Around Here ** 
Table 6 shows the estimates for the model for people with a rural hukou. Some coefficients are similar across destinations, but there are also differences. The estimates indicate that for 12 out of 14 cases, a specific ethnic minority status statistically significantly correlates negatively with probability for rural to urban migration. This is the case for destinations within as well as outside the province where the person has his or her hukou. The largest exceptions from this pattern are that Korean ethnicity leads to a higher probability to migrate. This is consistent with what several authors have reported, namely that the Korean ethnic minority in China differs from the country's other ethnic minorities in that a higher probability to move can be expected. For example, since China opened up investments from South Korea (and other foreign countries), a labour market has appeared for middlemen with a mastery of the Korean language and culture, see for example Zheng (1998, 1999); Piao (2009); Piao (2013) and Choi (2001). In addition, Hui ethnicity is statistically significantly positively correlated with migration to almost all types of destinations which is consistent with what Gustafsson and Ding (2014) report from Ningxia.

In not less than 8 cases, minority ethnicity is negatively correlated with migration to a rural area in the same province and in as many as 12 cases with migration to a rural area outside the province. We will return to the magnitude of the relationships after first having discussed how other variables and migration are related according to Table 6.

Family status has a clear, expected relationship with probability to move. For several destinations unmarried females have the highest probability to move, while the larger the number of children a married woman has, the smaller her probability to move. Being a married man reduces the probability of migrating to most types of destinations, except for a destination to a rural area in the same province. Probability to migrate decreases continuously by age from age 20 on for rural destinations and from age 30 on for urban destinations. Migration to urban areas increases continuously by level of education, and to rural areas after the level of junior middle school. Ill health and out-of-province migration are negatively related. We also report that expected income at the origin and most types of migration are statistically negatively related, migration to urban areas outside the province being the exception. We do not report all coefficients for the estimated province dummies, many of which are statistically significant and not of trivial size. 
** Figure Three Around Here **

In order to illustrate the magnitude of coefficients we have computed the probability to stay and to migrate for each of the four different destinations for a person with given characteristics. Figure 3.1 refers to an unmarried healthy male. This individual is of Han ethnicity and lives in rural Heilongjiang, a province with a proportion of migrants at the mean for China. It is assumed that the person lives in a county where the expected income if staying is at the mean for rural China. However, the person can be of a different age and can have a different education. We see that for the individual with a short education, the probability of staying is under 60 percent for the person aged 30 or under and thereafter increases rapidly by age. For a person with an education of senior middle school and aged 30 or under, the probability to stay is around onethird and actually under 20 percent for those with college or longer educations. The other extreme is of being over age 55 and having a short education, where the probability of staying is about 90 percent.

Where do these types of migrants move? Figure 3.2 shows that the probability of moving to an urban area in the same province is under 25 percent if being at most aged 30 while Figure 3.3 shows that the probability to move to an urban area in another province is almost 50 percent. Figures 3.4 and Figure 3.5 illustrate the much lower probabilities of moving to a rural area and that in such cases, probabilities do not vary much by education.

** Figure Four Around Here **

Figure 4.1 illustrates how probability to stay in a rural area can vary by province of origin for a male with different ages in three departure provinces. The person is assumed to be healthy, has completed junior middle school and lives in a county with average expected income for rural China. As province of origin we have chosen, in addition to Heilongjiang (with the mean probability to migrate), the two extremes Anhui (with the highest probability to migrate) and Shanxi (with the lowest probability to migrate). A very large variation across province of origin 
is illustrated. While the probability to stay for a young adult with a hukou in Anhui is only about 20 percent, the probability is over 80 percent for a young adult with a hukou in Shanxi.

Figure 4.2 illustrates how the probability to move to an urban destination in the same province is highest if the person is registered in rural Heilongiang, followed by Shanxi and is lowest if the person comes from Anhui. In contrast Figure 4.3 illustrates that the much higher probability to migrate to an urban area in another province is rather high when the person comes from Anhui than from the other two provinces. Young adults with a hukou in rural Anhui also have a rather high probability to migrate to a rural destination in another province, which is less frequently the case when having a hukou in Heilongjiang and particularly in Shanxi.

After thus having shown the larger contours of migration from rural areas, we will now illustrate how predictions for minority and majority persons differ when the persons are living in the same location and also have the same characteristics (as considered in the estimated models). The person chosen is an unmarried man, aged 26 to 30, who is healthy, has completed junior middle school, and lives in a county with average income for rural China. For each of the minorities studied we show predictions made, assuming the person lives in the province having the highest concentration of this particular minority. The exception is for the Tibetan minority where we choose Qinghai as very few Han live in Tibet. In this figure we can thus compare majority and minority person living in the same province and location and having the same characteristics. Accordingly, the figure makes it possible to compare for example a Uyghur person living in Xinjiang with a Han person also living in Xinjiang, both with the same characteristics. The figure also makes it possible to compare persons living in different provinces.

** Figure Five Around Here **

The bars in Figure 5.1 illustrate that the probability to stay for persons with given characteristics and origins but with different ethnicity is higher in most cases for an ethnic minority person than for a majority person. However, the variation across province of origin is larger. People with a hukou in Guangxi, Guizhou and Hunan have a much lower probability to stay than for those living in most other provinces shown in the figure. The mirror image is that 
people from these three provinces have a relatively high probability to move to another province, particularly to an urban destination (see Figure 5.2 and Figure 5.3). A minority person living in Guangxi, Guizhou or Hunan actually has a smaller probability to stay than a majority person living in Yunnan, for example. Still it is true that the probability to stay for a majority person living in Yunnan is lower than for a Bai person or Yi person living in Yunnan. The figure also illustrates that the lower probability for a rural Korean in Jilin to stay can be attributed to a comparably high probability to move to a city in another province.

Why is the probability to move so low for particularly Uyghur and Tibetan, while the probability is not equally low for some of the other minorities? Two possible reasons discussed in Section 2 are consistent with the variation in probability across ethnic groups. We are referring to difficulty finding a job, and the probably high cohesion within the ethnicity as documented by the very high rates of endogamy in Table 2. The third possible explanation, the comparatively low labour force participation rate among females, does not fit well with the findings. True, Uyghur urban females have a comparably low labour force participation rate, but Tibetan urban females do not. In addition Korea females as well as Hui females have low labour force participation rates, yet still have a higher probability to migrate than the majority.

\section{Modelling Urban People's Migration}

We now turn to migration for people with an urban hukou. The modelling strategy is very similar to how we modelled people having a rural hukou, but instead of defining four destinations we define three: urban locations within the same province, urban locations in another province and rural locations. This is motivated by the fact that the number of persons who have moved from an urban to a rural location is fairly low, making it less meaningful to distinguish between different categories of destinations. Our data shows that people with an urban hukou who live in rural areas are rather different from the rural "stayers" when it comes to occupation as well as ownership-sector. Thus while 81 percent of the rural stayers were classified as farmers, the corresponding proportion among urban to rural migrants was only 5 percent. While 64 percent of the urban to rural migrants studied here worked in private firms, as self-employed or in a state-owned firm, the corresponding proportion among rural stayers was as 
low as 13 percent. We use the same explanatory variables as for migration by people with a rural hukou, see Table 5.

** Table Seven Around Here **

In several respects the pattern relating migration of people with an urban hukou to various variables is similar to the corresponding pattern we have found for migration originating in rural China, See Table 7. The probability to migrate to all destinations is negatively related to expected income at the city of origin. However, the relationships are in some cases not equally strong as those for rural hukou holders. For example, migration probability is highest for young persons and decreases clearly by age, but negligibly after age 45 . Similarly, propensity to migrate increases in several cases by level of education. However, the relationship is not as pronounced between lower levels as among rural hukou holders.

Turning to our main interest, how ethnicity is related to probability to migrate, the main conclusion from Table 7 is that the pattern is much different among urban hukou holders than for rural hukou holders covered in the previous section. There are only two examples of ethnic minority status being negatively related to the probability to migrate to an urban destination within the same province: Uyghur ethnicity and (at a lower degree of statistical significance) and Miao ethnicity. There are four examples of minority ethnicity being negatively related to migration to a city located in another province. This is the case for Zhuang, Hui, Tibetan and Uyghur. However, there are also two examples of minority ethnicity being positively related to the probability of migration to a city in another province: Korean and Manchu. Turning to the rather small urban to rural migration, we have found not less than seven examples of ethnic minority being positively related to migration: Korean, Dong, Miao, Yao, Manchu, Mongol and Tibetan.

\section{Conclusion}

In this article we have used a subsample of the 2005 sample of China's Inter-Census Survey to investigate migration of ethnic minorities and the majority in China. Persons who had lived in 
another county/ city than where they were registered for at least six months at the time of the survey were defined as a migrant. The analysis was conducted on persons aged 16 to 60 who were not students. The 14 largest ethnic minority groups and the ethnic majority of Han were identified. It was found that among the Han majority, 11.9 percent had migrated while the corresponding proportion was lower for most of the ethnic minority groups studied, Koreans and Dong being the exceptions.

In order to better understand whether ethnicity per se affects the probability to migrate to different destinations, we specified and estimated one multinomial model for people with a rural hukou and another for people with an urban hukou. Explanatory variables included a string of dummy variables measuring ethnicity, education, age, family circumstances and health status. Circumstances at the place of origin was indicated by the expected income at the location as well as dummies for province. The estimated models revealed some patterns well known from previous research on migration in China and elsewhere. Probability to migrate decreases in many cases by age and with expected income at the origin and increases by education. Migration probability also differs by province of origin and by family circumstances, and regarding out-ofprovince migration, also by health status.

A major result is that in most cases, minority ethnicity reduces migration probability for people registered in rural China. This is particularly the case for migration to urban areas and for people belonging to the Uyghur and Tibetan ethnic groups. This might be due to larger difficulties than for others of making a living in an urban area as well as by large cohesion in the group as indicated by a high rate of endogamy. The former can in turn be due to several factors: Lack of access to networks at potential destinations which in turn can be traced to little previous migration, to lack of skills in Mandarin or local Han dialect as well as unequal treatment in the labour market and / or in other markets. Rural people belonging to the Mongolian, Bai, Yao and Tuija groups were also found to have lower probabilities to migrate than the ethnic majority and the same applies, although to a lesser extent to Miao, Bouyei, Yi, Zhuang, Dong and Manchu. The exceptions from the pattern of lower probability for rural ethnic minorities to move are the Korean and Hui who have higher probabilities to move than the majority. 
The lower probability for most ethnic minorities to move has consequences for the spatial distribution of people in China. Most of China's cities will continue to be places with less ethnic diversity than that suggested by the population statistics for the country as a whole. The fact that comparatively few persons belonging to ethnic minorities relocate can be a force that reduces the pace of economic development among the minorities. This can be viewed as problematic from a social justice point of view and can possibly lead to social tensions.

Another major conclusion is that the pattern on how ethnicity is related to migration probability differs between persons possessing a rural hukou and those possessing an urban hukou. Examples for holders of an urban hukou of minority ethnicity being related to migration to an urban destination are few. However, we found that in not less than seven cases, ethnic minority status is positively related to the probability to migrate to a rural destination. 


\section{References}

Abuduwaili Yimiti and Hu, Hongwei. 2010. "The Personal Characteristics of Uyghur Migrants and the Related Problems and Policy: Based on the Survey in Urumqi and Xian." Journal of South-Central University for Nationalities (Humanities and Social Sciences) 30 (1): 40-44. (in Chinese)

Cai, Fang. 2011. "Hukou System Reform and Unification of Rural-urban Social Welfare." China \& World Economy 19: no 3, 33-48.

Chan, Kam Wing. 2012. "Migration and Development in China: Trends, Geography and Current Issues." Migration and Development 1: 187-205.

Chen, Y. 2008. "The Factors of Repulsion Met by Ethnic Minority when They Try to Integrate into Urban Areas." Journal of South-Central University of Nationalities (Humanities and Social Sciences) 192 (8): 34-37. (In Chinese)

Cheng, Mingwang and Shi, Qinghua and Xu, Jianxia. 2006. "From Malthus to Sollow: An Explanation for the Motivation and Obstacles Affecting Farmer Labour Emigration in China." Economic Research Journal 4: 68-78. (in Chinese)

Choi, Woo-Gil. 2001. "The Korean Minority in China: The Change of its Identity.” Development and Society 30 (1): 119-141.

Connelly, Rachel, Roberts, Kenneth and Zheng Zhenzheng. 2012. "The Role of Children in the Migration Decisions of Rural Chinese Women.” Journal of Contemporary China 21: 93-111.

Fan, Cindy C. 2008. China on the Move: Migration, the State, and the Household. London and New York: Routledge.

Gao, Fang. 2008. "What it Means to be a 'Model Minority': Voices of Ethnic Koreans in Northeast China." Asian Ethnicity 9(1): 55-67.

Gustafsson, Bjorn and Ding, Sai. 2014. "Why is there no Income Gap between the Hui Muslim Minority and the Han Majority in Rural Ningxia China?" China Quarterly, 220, 968 - 987.

Hannum, Emily. and Xie, Yu. 1998. "Ethnic Stratification in Northwest China: Occupational Differences between Han Chinese and National Minorities in Xinjiang, 1982-1990." Demography 35: 323-333.

Hasmath, Reza. 2008. "The Big Payoff? Educational and Occupational Attainments of Ethnic Minorities in Beijing." European Journal of Development Research 20: 104-116. 
Hasmath, Reza. 2011. "From Job Search to Hiring and Promotion: the Labour Market Experience of Ethnic Minorities in Beijing.” International Labour Review 150 (1-2): 189-201. Hopper, Ben. and Webber, Michael. 2009. "Migration, Modernisation and Ethnic Estrangement: Uyghur Migration to Urumqi, Xinjiang Uyghur Autonomous Region, PRC.” Inner Asia 11: 173-203.

Howell, Anthony and Fan, Cindy. 2011. "Migration and Inequality in Xinjiang: A Survey of Han and Uyghur Migrants in Urumqi." Eurasian Geography and Economics 52(1): 119-139. Iredale, Robyn., Bilik., Naran and Guo., Fei (Eds). 2003. China's Minorities on the Move. Selected Case Studies. Armonk, New York, London, England: M.E. Sharpe.

Kaup, Katherine Palmer. 2000. Creating the Zhuang. Ethnic Politics in China. Boulder, London: Lynne Rienner Publishers.

Knight, John and Song, Lina. 2005. Towards a Labour Market in China. Oxford: Oxford University Press.

Li, Qiang. 2003. "An Analysis of Push and Pull Factors in the Migration of Rural Workers in China." Social Sciences in China 1(5): 125-136. (in Chinese)

Ma, Zhongdong. 2001. "Urban Labour-force Experience as a Determinant of Rural Occupation Change: Evidence from Recent Urban-rural Return Migration in China." Environment and Planning 33: 237-255.

Maurer-Fazio, Margaret. 2012. "Ethnic Discrimination in China's Internet Job Board Labour Market." IZA Journal of Migration 1: 1-12.

Maurer-Fazio, Margaret, Huges, James, W. and Zhang, Dandan. 2010. "A Comparison and Decomposition of Reform-era Labour Force Participation Rates of China's Ethnic Minorities and Han Majority.” International Journal of Manpower 31: 138-162.

Mullaney, Thomas, S. 2011. Coming to Terms with the Nation. Berkley and Los Angeles, California: University of California Press.

Paik, Wooyeal and Ham, Myungsik, 2012. "From Autonomous Areas to Non-Autonomous Areas: the Politics of Korean Minority Migration in Contemporary China." Modern China 38: 110-133.

Piao, Guangxing. 2009. “Chinese Koreans' International Migration and their World-wide Social Network." Journal of Minzu University of China 5: 18-24. (in Chinese) 
Piao, Shengzhen, 2013. “The Influence of China and Korea Establishing Diplomatic Relations on the Population Flow of Korea Nationality." Heilongjiang Ethnicity Journal 2: 35-39. (in Chinese)

Ren, Qiang and Yuan, Sin (2003) "Impact of Migration to Xinjiang Since the 1950s" in Iredale, Robyn., Bilik., Naran and Guo., Fei (Eds). 2003. China's Minorities on the Move. Selected Case Studies. Armonk, New York, London, England: M.E. Sharpe.

Shen, Kunrong and Yu, Jixiang. 2011. "The Influence of Rural Migrant's Migration on the Urban People's Income.” Management World 3: 58-65. (in Chinese)

Shi, Shih-Jiunn. 2012. “Towards Inclusive Social Citizenship? Rethinking China's Social Security in the Trend towards Urban-rural Harmonisation.” Journal of Social Policy 41: 789810.

Sun, Wenkai and Bai, Chongen and Xie, Peichu. 2011. "The Effect on Rural Mobility from Registration System Reform in China.” Economic Research Journal 1: 28-41. (in Chinese)

Tang, Duoxian. 2006. "The Characteristics of Ethnic Minority Migrants in the Big City in Northwest China: Take Lanzhou City for Example." Ethno-National Studies 1: 31-40. (in Chinese)

Tong, Yuing and Piotrowski, Martin. 2012. "Migration and Health Selectivity in the Context of Internal Migration in China, 1997-2009.” Population Research and Policy Review 31: 497543.

Vinod, Mishra and Russell, Smyth. 2013. "Economic Returns to Schooling for China's Korean Minority." Journal of Asian Economics 24: 89-102

Weimin, Zhang. no year. "China's Inter-census Survey in 2005." http://www.ancsdaap.org/cencon2005/Papers/China/China.Zhang.Weimin.etal.pdf. (Accessed 19 February 2014.

Wu, Jiaping. 2012. “The Rise of Ethnicity under China's Market Reform.” International Journal of Urban and Regional Research, online publication 28 September 2012.

Wu, Xiaogang and Song, Xi. 2014. "Ethnic Stratification amid China's Economic Transition: Evidence from the Xinjiang Uyghur Autonomous Region.” Social Science Research 44: 158172.

Xiang, Hua. 2012. “Chinese Koreans' Integration into the Urban Areas: Take the Three Cities of Weihai, Qingdao, Yantai for Example.” Heilongjiang Ethnicity Journal 4: 59-65. (in Chinese) 
Yang Du, Park, Albert, Wang Sangui. 2005. "Migration and Rural Poverty in China." Journal of Comparative Economics 33: 688-709.

Yao, Xianguo and Lai, Puqing. 2004. "Urban-rural Hukou Differentials in Chinese Labour Relations." Economic Research Journal 7: 82-90. (In Chinese)

Zai, Liang. 2001. "The Age of Migration in China." Population and Development Review 27: 499-524.

Zang, Xiaowei. 2008. "Market Reform and Han-Muslim Variation in Employment in the Chinese State Sector in a Chinese City.” World Development 36: 2341-2352.

Zang, Xiaowei. 2010. "Affirmative Action, Economic Reforms, and Han-Uygur Variation in Job Attainment in the State Sector in Urumqi." China Quarterly 202: 344-361

Zang, Xiaowei. 2011. "Uyghur-Han Earnings Differential in Urumchi." The China Journal, 65: 141-155.

Zang, Xiaowei. 2012. "Age and the Cost of Being Uyghur in Urumqi." China Quarterly 210: 419-434.

Zhang, Wenhong and Lei, Kaichun. 2008. "The Urban New Immigrants' Social Integration: Internal Structure, Present Situation and Influential Factors." Sociological Studies 5: 117-141. (in Chinese)

Zhao, Yaohui. 2002. "Causes and Consequences of Return Migration: Recent Evidence from China." Journal of Comparative Economics 30: 376-394.

Zheng, Xinzhe. 1998. "The Migration of Chinese Korean and Social Stabilization." Manzu Minority Research 4: 74-85. (in Chinese)

Zheng, Xinzhe. 1999. "The Influence of Chinese Koreans' Migration and the Relevant Policy." Journal of Yanbian University (Social Science) 3: 66-73. (in Chinese)

Zhong, Xiaohan. 2006. "Labor Flow and Wage Disparity." Social Sciences in China 1: 42-51. (In Chinese) 
Table 1 Population size, rate of urbanization and provincial location of 14 ethnic minorities and majority in China 2005

\begin{tabular}{|c|c|c|c|c|}
\hline Minzu & population & size & urban hukou & provincial location of ethnic groups in China \\
\hline & number (million) & $\begin{array}{l}\text { Percent } \\
(\%)\end{array}$ & $(\%)$ & (urban+rural areas) \\
\hline Han & 1179.12 & 91.57 & 29.3 & $/ / /$ \\
\hline Korean & 1.88 & 0.14 & 48.4 & Jilin (64. 1\%) Heilong jiang (17. 3\%) \\
\hline Dong & 2.92 & 0.23 & 10.3 & Guizhou (64. 0\%) Hunan (25. 6\%) \\
\hline Zhuang & 16.55 & 1.29 & 13.4 & Guangxi (80.3\%) \\
\hline Tujia & 8.19 & 0.64 & 13.3 & Hunan (30.6\%) Hubei (27. 4\%) Chongqing (21.0\%) \\
\hline Miao & 9.18 & 0.71 & 8.2 & Guizhou (47. 5\%) Yunnan (21. 4\%) Hunan (14. 7\%) \\
\hline Hui & 10.20 & 0.79 & 33.4 & Ningxia (31. 6\%) Qinghai (15. 5\%) Gansu (14. 1\%) Yunnan (6. 4\%) Xinjiang (5. 3\%) \\
\hline Yao & 2.72 & 0.21 & 9.2 & Guangxi (32.3\%) Guangdong (30\%) Hunan (21. 5\%) \\
\hline Manchu & 10.54 & 0.82 & 32.4 & Liaoning (49. 1\%) Hebei (14. 5\%) Jilin (12.6\%) \\
\hline Bouyei & 2.92 & 0.23 & 8.9 & Guizhou $(94.4 \%)$ \\
\hline Mongol & 5.90 & 0.46 & 31.6 & Inner Mongolia (67. 6\%) Liaoning (8. 4\%) \\
\hline Bai & 1.90 & 0.15 & 13.2 & Yunnan $(92.3 \%)$ \\
\hline Yi & 8.24 & 0.64 & 5.8 & Yunnan $(81.4 \%)$ \\
\hline Tibetan & 5.85 & 0.46 & 9.7 & Tibet (56. 0\%) Qinghai (22. 1\%) \\
\hline Uyghur & 9.23 & 0.72 & 17.5 & Xinjiang $(99.4 \%)$ \\
\hline others & 12.37 & 0.94 & 10.6 & $/ / /$ \\
\hline total & 1287.70 & $100 \%$ & 27.83 & $/ / /$ \\
\hline
\end{tabular}

Note:1) The number and percentage in columns 2 and 3 are the average of results from the census 2000 and 2010;

2) The percentage in columns 4 and 5 are obtained by analyzing the subsample of China's Inter-census Survey 2005 ;

3) When we calculate the rate of urbanization and provincial location of each ethnic group, all age observations are included. 
Table 2 Education and marriage among 14 Ethnic minorities and Han in China 2005

\begin{tabular}{|c|c|c|c|c|c|c|}
\hline & \multicolumn{5}{|c|}{ Education } & \multirow{2}{*}{$\begin{array}{r}\text { marriage } \\
\text { Endogamy }(\%)\end{array}$} \\
\hline & rural-male & rural-female & urban-male & urban-female & total & \\
\hline Korean & 9.29 & 8.76 & 11.80 & 11.31 & 10.24 & 88.1 \\
\hline Dong & 7. 46 & 5.96 & 12.20 & 11. 20 & 7.34 & 77.2 \\
\hline Han & 8.12 & 6.95 & 11. 48 & 10.87 & 8.68 & 98.3 \\
\hline Zhuang & 7.97 & 6.69 & 11.78 & 11.08 & 7.97 & 86.9 \\
\hline Tujia & 7.68 & 6.23 & 12.16 & 11.10 & 7.67 & 76.9 \\
\hline Miao & 6.58 & 4. 47 & 12.04 & 10.42 & 6.06 & 80.7 \\
\hline Hui & 6.12 & 4.17 & 10.75 & 10. 26 & 7. 11 & 87.5 \\
\hline Yao & 7.10 & 5.33 & 12.28 & 11.79 & 6.87 & 81.9 \\
\hline Manchu & 8.21 & 7.70 & 11. 69 & 11. 42 & 9.14 & 48.9 \\
\hline Bouyei & 6.91 & 4.55 & 12.32 & 11. 19 & 6.26 & 79.7 \\
\hline Mongolia & 7.74 & 6.94 & 12.11 & 11.73 & 8. 79 & 65.0 \\
\hline Bai & 7.50 & 5.85 & 11.93 & 11.60 & 7. 40 & 77.5 \\
\hline Yi & 6.35 & 4.92 & 11.56 & 11.10 & 6.02 & 80.9 \\
\hline Tibetan & 3.93 & 2. 40 & 9.79 & 7.92 & 3. 80 & 94.2 \\
\hline Uyghur & 7.06 & 6.77 & 11.23 & 10.86 & 7. 74 & 98.7 \\
\hline others & 6.09 & 4. 42 & 11.41 & 10.62 & 5.94 & $/ / /$ \\
\hline total & 7.93 & 6.75 & 11.47 & 10.86 & 8.49 & $1 / 1$ \\
\hline
\end{tabular}

Note:1) Source: Authors' computations from subsample of China's Inter-census Survey 2005;

2) The average year of education is computed for persons aged 21-60 and who are not students. 
Table 3 Different kinds of migrants according to the 2005 census sample survey-number of observations

\begin{tabular}{|c|c|c|c|c|c|}
\hline & & Number of observations & $\begin{array}{c}\text { estimated } \\
\text { population size } \\
\text { (million) }\end{array}$ & percentage & percentage \\
\hline \multirow[t]{4}{*}{ Stayers } & total & $2,231,082$ & 1115.54 & & 86.29 \\
\hline & Adults & $1,440,874$ & 720.44 & 64.58 & \\
\hline & Children & 517,834 & 258. 92 & 23.21 & \\
\hline & elders & 272,374 & 136.19 & 12.21 & \\
\hline intra city/county migrants & & 113,916 & 56.96 & & 4.41 \\
\hline \multirow[t]{6}{*}{ inter city/county migrants } & total & 226,836 & 113.42 & & 8.77 \\
\hline & migrants here studied & 182,008 & 91.00 & 80.24 & \\
\hline & recent migrants & 1,355 & 0.68 & 0.6 & \\
\hline & student migrants & 8,274 & 4.14 & 3.65 & \\
\hline & children-migrants & 25,117 & 12.56 & 11.07 & \\
\hline & elder-migrants & 10,082 & 5.04 & 4.44 & \\
\hline undetermined yet & & 13,644 & 6.82 & & 0.53 \\
\hline Total & & $2,585,478$ & 1292.74 & 100 & 100 \\
\hline
\end{tabular}

1) Source: Authors' computations from subsample of China's Inter-census Survey 2005;

2) Definition of each kind of migrant:

Migrants here studied: A person aged between 16 and 60, and who is not a students and who have stayed at the

destination at least six months.

Recent migrants:A person aged between 16 and 60 who have stayed at the destination

less than six months.

Student migrants: A person aged 16 to 60 who study in a

educational instituton. $16=\langle$ age $<=60$; study in school;

children-migrants:A person aged less than 16 year and who

have migrated.

elder-migrants: A person aged 60

years or more and who has

migrated. 
Table 4 Migrants here studied by origin and destination. Number of observations. Table 4-1

$$
\text { rural place urban place Total }
$$

$\begin{array}{llll}\begin{array}{l}\text { rural } \\ \text { hukou } \\ \text { urban } \\ \text { hukou }\end{array} & 42514(23.4 \%) & 89496(49.2 \%) & 132010(72.5 \%) \\ & 8310(4.6 \%) & 41688(22.9 \%) & 49998(27.5 \%) \\ \text { Total } & 50824(27.9 \%) & 131184(72.1 \%) & 182008(100 \%)\end{array}$

Table 4-2

\begin{tabular}{l|l|l|l|l|l}
\hline & \multicolumn{2}{|c|}{ rural place } & \multicolumn{2}{|c|}{ urban place } & \\
\hline & within & between & within & between & Total \\
$\begin{array}{l}\text { rural } \\
\text { hukou } \\
\begin{array}{l}\text { urban } \\
\text { hukou }\end{array}\end{array}$ & $11711(6.4 \%)$ & $30803(16.9 \%)$ & $27740(15.2 \%)$ & $61756(33.9 \%)$ & $132010(72.5 \%)$ \\
& $5081(2.8 \%)$ & $3229(1.8 \%)$ & $25408(14.0 \%)$ & $16280(8.9 \%)$ & $49998(27.5 \%)$ \\
\hline Total & $16792(9.2 \%)$ & $34032(18.7 \%)$ & $53148(29.2 \%)$ & $78036(42.9 \%)$ & $182008(100 \%)$ \\
\cline { 2 - 6 } & \multicolumn{2}{|c|}{$50824(27.9 \%)$} & \multicolumn{2}{|c|}{$131184(72.1 \%)$} & $182008(100 \%)$ \\
\hline
\end{tabular}

Notes:

1) Source: Authors' computations from subsample of China's Inter-census Survey 2005.

2) Migrants here studied: A person aged between 16 and 60, and who is not a student and has stayed at the destination at least six months. 


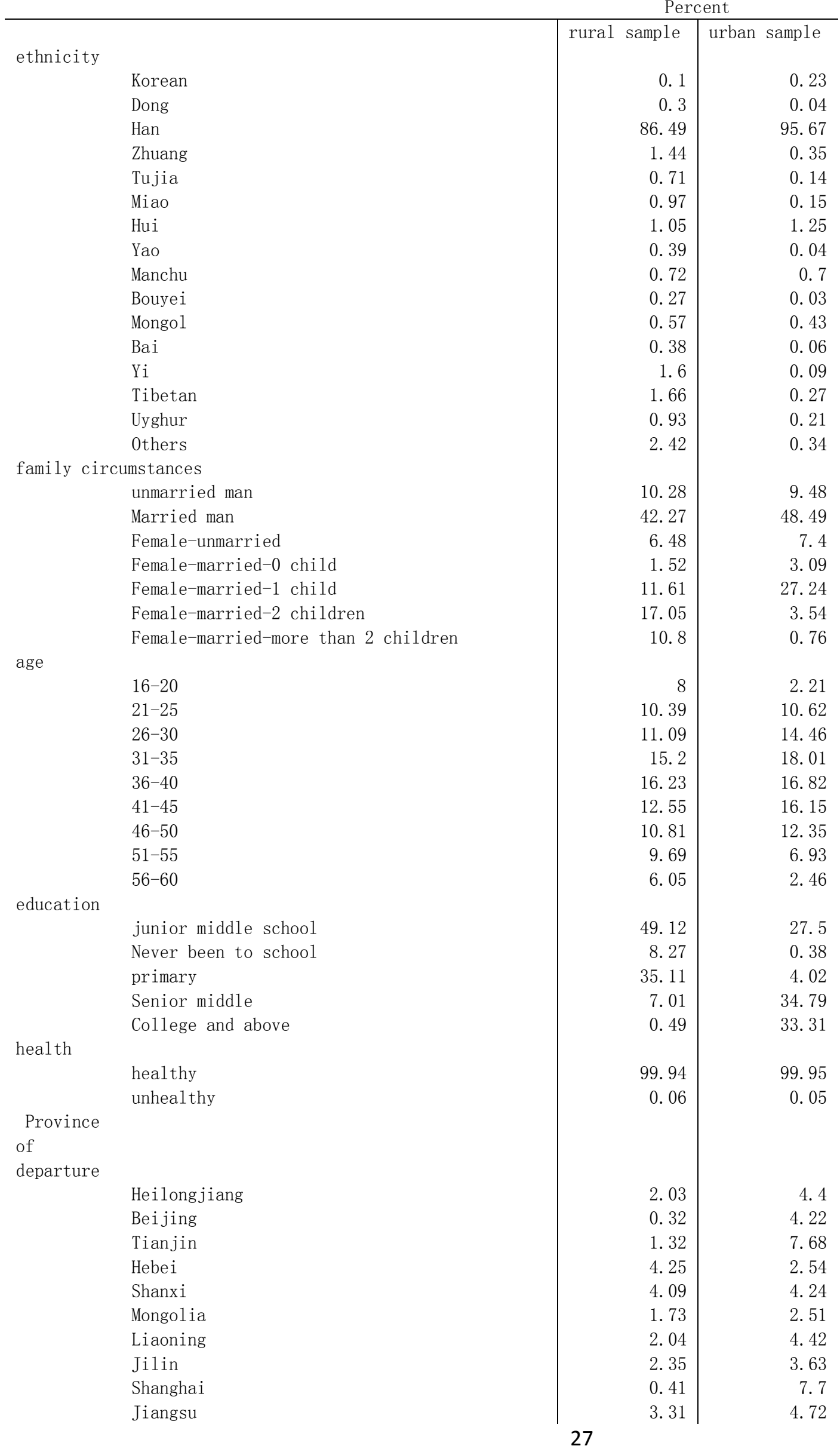




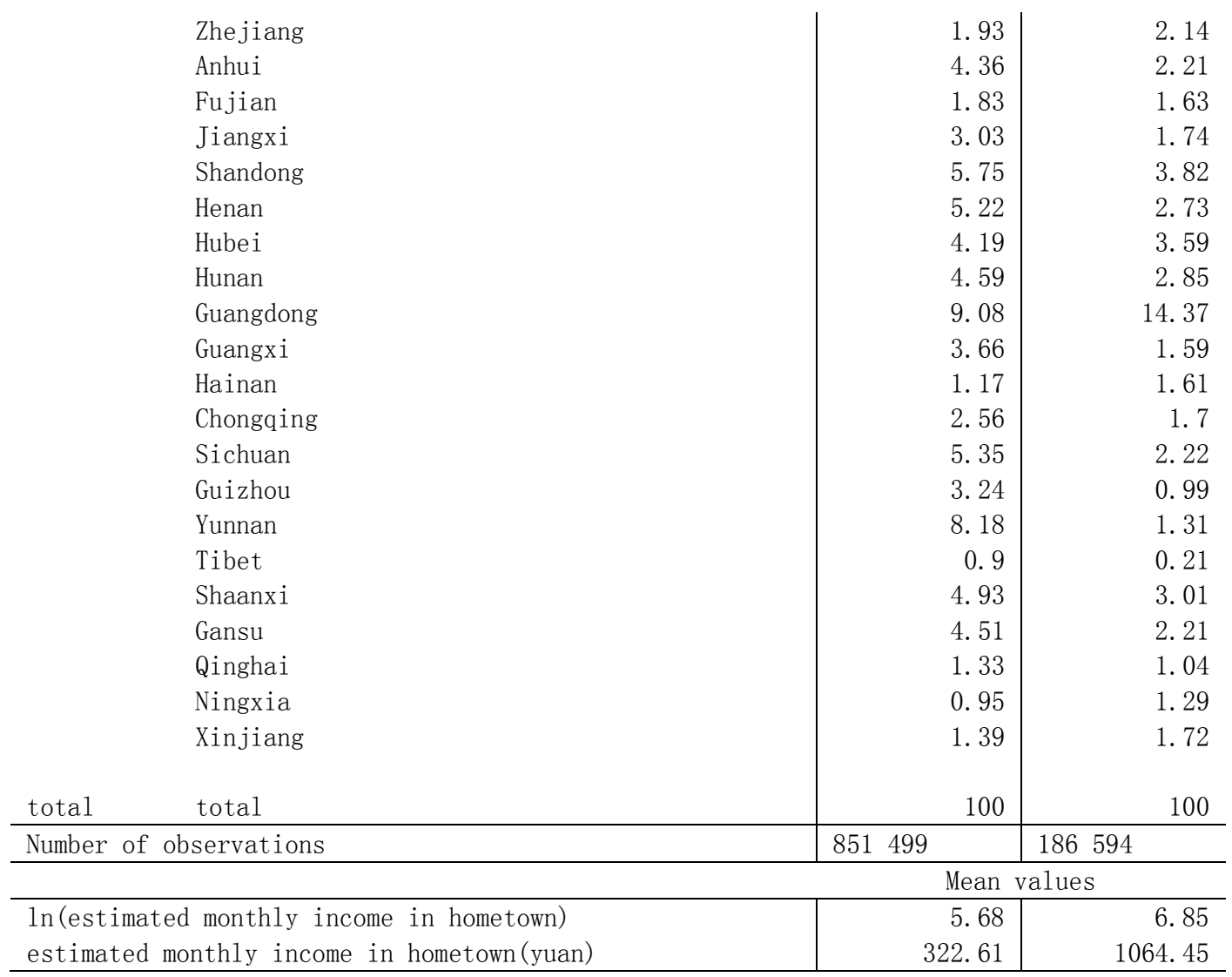

Note:1) Source: Authors' computations from subsample of China's Inter-census Survey 2005.

2) For the calculation of "estimated monthly income in hometown" see Section 4 of the text.

3) The monthly income here includes labor income, but not capital income, transfers received and income from own production or imputed rent of owner occupied housing. 
Table 6 Estimated Multinomial logit for migration among adult persons originating in rural China in 2005

\begin{tabular}{|c|c|c|c|c|c|}
\hline & $(1)$ & $(2)$ & (3) & (4) & $(5)$ \\
\hline & Rural stay & \multicolumn{4}{|c|}{ Destination } \\
\hline \multirow[t]{2}{*}{ VARIABLES } & & \multicolumn{2}{|r|}{ Urban } & \multicolumn{2}{|r|}{ Rural } \\
\hline & & Same province & Different provinces & Same province & Different provinces \\
\hline \multicolumn{6}{|l|}{$\begin{array}{l}\text { Ethnicity (Han, omitted } \\
\text { category) }\end{array}$} \\
\hline Korean & & $\begin{array}{l}0.502 * * \\
(2.491)\end{array}$ & $\begin{array}{c}1.551 * * * \\
(12.15)\end{array}$ & $\begin{array}{l}0.661 * * \\
(2.400)\end{array}$ & $\begin{array}{l}-1.016^{*} \\
(-1.745)\end{array}$ \\
\hline Dong & & $\begin{array}{c}-0.375 * * \\
(-2.051)\end{array}$ & $\begin{array}{c}-0.270 * * * \\
(-3.606)\end{array}$ & $\begin{array}{c}-0.353 \\
(-1.376)\end{array}$ & $\begin{array}{c}-0.770 * * * \\
(-7.252)\end{array}$ \\
\hline Zhuang & & $\begin{array}{c}-0.380 * * * \\
(-4.176)\end{array}$ & $\begin{array}{c}-0.656 * * * * \\
(-15.00)\end{array}$ & $\begin{array}{c}-0.399 * * * \\
(-3.701)\end{array}$ & $\begin{array}{c}-0.422 * * * \\
(-7.918)\end{array}$ \\
\hline Tujia & & $\begin{array}{c}-1.495 * * * \\
(-8.077)\end{array}$ & $\begin{array}{c}-0.610 * * * * \\
(-11.24)\end{array}$ & $\begin{array}{l}-0.444 * * \\
(-2.125)\end{array}$ & $\begin{array}{c}-0.546 * * * \\
(-8.303)\end{array}$ \\
\hline Miao & & $\begin{array}{c}-0.898 * * * \\
(-6.688)\end{array}$ & $\begin{array}{c}-0.737 * * * * \\
(-12.33)\end{array}$ & $\begin{array}{l}-0.0753 \\
(-0.699)\end{array}$ & $\begin{array}{c}-0.718 * * * \\
(-10.86)\end{array}$ \\
\hline Hui & & $\begin{array}{c}0.288 * * * \\
(2.875)\end{array}$ & $\begin{array}{c}0.287 * * * \\
(3.315)\end{array}$ & $\begin{array}{c}0.646 * * * \\
(6.860)\end{array}$ & $\begin{array}{c}0.143 \\
(1.431)\end{array}$ \\
\hline Yao & & $\begin{array}{c}-1.509 * * * \\
(-8.229)\end{array}$ & $\begin{array}{c}-1.102 * * * * \\
(-11.10)\end{array}$ & $\begin{array}{c}-0.639 * * * \\
(-3.497)\end{array}$ & $\begin{array}{c}-0.712 * * * \\
(-6.629)\end{array}$ \\
\hline Manchu & & $\begin{array}{c}-0.311 * * * \\
(-3.245)\end{array}$ & $\begin{array}{c}-0.352 * * * \\
(-3.501)\end{array}$ & $\begin{array}{l}-0.160 \\
(-1.256)\end{array}$ & $\begin{array}{l}-0.0985 \\
(-0.795)\end{array}$ \\
\hline Bouyei & & $\begin{array}{c}-0.828 * * * \\
(-3.205)\end{array}$ & $\begin{array}{c}-1.012 * * * \\
(-8.334)\end{array}$ & $\begin{array}{c}-0.953 * * * \\
(-2.943)\end{array}$ & $\begin{array}{c}-0.886 * * * \\
(-7.447)\end{array}$ \\
\hline Mongol & & $\begin{array}{c}-1.670 * * * \\
(-11.16)\end{array}$ & $\begin{array}{c}-0.805 * * * \\
(-6.195)\end{array}$ & $\begin{array}{c}-0.680 * * * \\
(-5.389)\end{array}$ & $\begin{array}{c}-1.110 * * * \\
(-6.931)\end{array}$ \\
\hline Bai & & $\begin{array}{c}-1.011 * * * \\
(-4.321)\end{array}$ & $\begin{array}{c}-1.018 * * * * \\
(-4.433)\end{array}$ & $\begin{array}{l}-0.0411 \\
(-0.301)\end{array}$ & $\begin{array}{c}-1.571 * * * \\
(-5.141)\end{array}$ \\
\hline Yi & & $\begin{array}{c}-0.799 * * * \\
(-7.334)\end{array}$ & $\begin{array}{c}-2.289 * * * \\
(-17.14)\end{array}$ & $\begin{array}{c}-0.611 * * * \\
(-6.677)\end{array}$ & $\begin{array}{c}-2.151 * * * \\
(-15.86)\end{array}$ \\
\hline Tibetan & & $\begin{array}{c}-2.038 * * * \\
(-7.545)\end{array}$ & $\begin{array}{c}-2.601 * * * * \\
(-14.79)\end{array}$ & $\begin{array}{c}-0.757 * * * \\
(-4.733)\end{array}$ & $\begin{array}{c}-2.983 * * * \\
(-12.25)\end{array}$ \\
\hline Uyghur & & $\begin{array}{c}-2.634 * * * \\
(-10.38)\end{array}$ & $\begin{array}{c}-0.825 * * \\
(-2.017)\end{array}$ & $\begin{array}{c}-1.100 * * * \\
(-5.656)\end{array}$ & $\begin{array}{c}-2.888 * * * \\
(-5.290)\end{array}$ \\
\hline others & & $\begin{array}{c}-1.077 * * * \\
(-12.50)\end{array}$ & $\begin{array}{c}-1.138 * * * \\
(-13.27)\end{array}$ & $\begin{array}{c}-0.503 * * * \\
(-6.658)\end{array}$ & $\begin{array}{c}-0.916^{* * *} \\
(-10.94)\end{array}$ \\
\hline $\begin{array}{l}\text { Family circumstances } \\
\text { (unmarried man, omitted } \\
\text { category) }\end{array}$ & & & & & \\
\hline Married man & & $\begin{array}{c}-0.0688 * * \\
(-2.449)\end{array}$ & $\begin{array}{c}-0.428 * * * \\
(-22.92)\end{array}$ & $\begin{array}{l}0.249 * * * \\
(5.776)\end{array}$ & $\begin{array}{c}-0.123 * * * \\
(-4.923)\end{array}$ \\
\hline Female-unmarried & & $\begin{array}{c}0.488 * * * \\
(18.92)\end{array}$ & $\begin{array}{c}0.385 * * * \\
(21.55)\end{array}$ & $\begin{array}{c}0.141 * * * \\
(3.118)\end{array}$ & $\begin{array}{c}0.272 * * * \\
(11.34)\end{array}$ \\
\hline $\begin{array}{l}\text { Female-married-0 } \\
\text { child }\end{array}$ & & $\begin{array}{c}0.112 * * \\
(2.218)\end{array}$ & $\begin{array}{c}-0.342 * * * \\
(-9.581)\end{array}$ & $\begin{array}{l}0.638 * * * \\
(9.800)\end{array}$ & $\begin{array}{c}-0.0853^{*} \\
(-1.892)\end{array}$ \\
\hline Female-married-1 & & $-0.404 * * *$ & $-0.666 * * *$ & $0.140 * * *$ & $-0.424 * * *$ \\
\hline child & & $(-12.71)$ & $(-32.42)$ & (3.049) & $(-15.62)$ \\
\hline Female-married-2 & & $-0.779 * * *$ & $-0.933 * * *$ & $-0.286^{* * *}$ & $-0.692 * * *$ \\
\hline children & & $(-20.91)$ & $(-38.22)$ & $(-5.392)$ & $(-21.73)$ \\
\hline Female-married-more & & $-1.202 * * *$ & $-1.361 * * *$ & $-0.567 * * *$ & $-0.984 * * *$ \\
\hline than 2 children & & $(-23.88)$ & $(-34.18)$ & $(-8.417)$ & $(-20.36)$ \\
\hline Age (16-20,omitted category) & & & & & \\
\hline $21-25$ & & $\begin{array}{l}-0.0273 \\
(-1.034)\end{array}$ & $\begin{array}{l}0.0352 * * \\
(1.970)\end{array}$ & $\begin{array}{c}-0.136 * * * \\
(-3.127)\end{array}$ & $\begin{array}{c}-0.0859 * * * \\
(-3.627)\end{array}$ \\
\hline $26-30$ & & $\begin{array}{l}-0.0317 \\
(-0.971)\end{array}$ & $\begin{array}{l}0.0674 * * * \\
(3.050)\end{array}$ & $\begin{array}{l}-0.225 * * * \\
(-4.404)\end{array}$ & $\begin{array}{c}-0.181 * * * \\
(-6.206)\end{array}$ \\
\hline $31-35$ & & $\begin{array}{c}-0.154 * * * \\
(-4.392)\end{array}$ & $\begin{array}{c}-0.168 * * * \\
(-7.188)\end{array}$ & $\begin{array}{c}-0.471 * * * \\
(-8.750)\end{array}$ & $\begin{array}{c}-0.456 * * * \\
(-14.77)\end{array}$ \\
\hline $36-40$ & & $\begin{array}{c}-0.462 * * * \\
(-12.57)\end{array}$ & $\begin{array}{c}-0.614 * * * * \\
(-24.69)\end{array}$ & $\begin{array}{c}-0.689 * * * \\
(-12.38)\end{array}$ & $\begin{array}{c}-0.887 * * * \\
(-27.09)\end{array}$ \\
\hline $41-45$ & & $\begin{array}{c}-0.930 * * * \\
(-22.96)\end{array}$ & $\begin{array}{c}-1.146 * * * \\
(-40.70)\end{array}$ & $\begin{array}{c}-1.053 * * * \\
(-17.37)\end{array}$ & $\begin{array}{c}-1.403 * * * \\
(-37.45)\end{array}$ \\
\hline $46-50$ & & $\begin{array}{c}-1.386 * * * \\
(-30.26)\end{array}$ & $\begin{array}{c}-1.709 * * * \\
(-50.98)\end{array}$ & $\begin{array}{c}-1.491 * * * \\
(-22.06)\end{array}$ & $\begin{array}{c}-2.054 * * * \\
(-45.17)\end{array}$ \\
\hline $51-55$ & & $\begin{array}{c}-1.678 * * * \\
(-31.30)\end{array}$ & $\begin{array}{c}-2.161 * * * \\
(-53.60)\end{array}$ & $\begin{array}{c}-1.731 * * * \\
(-23.11)\end{array}$ & $\begin{array}{c}-2.722 * * * \\
(-47.57)\end{array}$ \\
\hline $56-60$ & & $\begin{array}{c}-1.970 * * * \\
(-27.30)\end{array}$ & $\begin{array}{l}-2.523 * * * \\
(-45.19)\end{array}$ & $\begin{array}{l}-1.870 * * * \\
(-20.60)\end{array}$ & $\begin{array}{c}-3.125 * * * \\
(-39.37)\end{array}$ \\
\hline $\begin{array}{l}\text { Education (junior middle, } \\
\text { omitted category) }\end{array}$ & & & & & \\
\hline Never been to school & & $\begin{array}{c}-0.197 * * * \\
(-4.043)\end{array}$ & $\begin{array}{c}-0.337 * * * \\
(-9.794)\end{array}$ & $\begin{array}{l}0.189 * * * \\
(3.582)\end{array}$ & $\begin{array}{l}-0.0532 \\
(-1.328)\end{array}$ \\
\hline primary & & $\begin{array}{c}-0.554 * * * \\
(-25.84)\end{array}$ & $\begin{array}{c}-0.439 * * * \\
(-31.29)\end{array}$ & $\begin{array}{c}-0.193 * * * \\
(-6.928)\end{array}$ & $\begin{array}{c}-0.186^{* * *} \\
(-10.75)\end{array}$ \\
\hline Senior middle & & $\begin{array}{c}0.984 * * * \\
(46.42)\end{array}$ & $\begin{array}{c}0.870 * * * \\
(55.32)\end{array}$ & $\begin{array}{c}0.519 * * * \\
(13.74)\end{array}$ & $\begin{array}{c}0.445 * * * \\
(18.85)\end{array}$ \\
\hline College and above & & $\begin{array}{c}2.025 * * * \\
(36.77)\end{array}$ & $\begin{array}{c}1.622 * * * \\
(35.68)\end{array}$ & $\begin{array}{l}1.128 * * * \\
(10.24)\end{array}$ & $\begin{array}{c}0.529 * * * \\
(6.246)\end{array}$ \\
\hline $\begin{array}{l}\text { Health (healthy, omitted } \\
\text { category) }\end{array}$ & & & & & \\
\hline unhealthy & & $\begin{array}{c}-0.607 \\
(-1.451)\end{array}$ & $\begin{array}{l}-0.486 * \\
(-1.866)\end{array}$ & $\begin{array}{c}-0.194 \\
(-0.383)\end{array}$ & $\begin{array}{l}-0.611^{*} \\
(-1.766)\end{array}$ \\
\hline Income if stay at hometown & & $\begin{array}{c}-0.380 * * * \\
(-12.02)\end{array}$ & $\begin{array}{c}0.00736 \\
(0.283)\end{array}$ & $\begin{array}{c}-0.238 * * * \\
(-5.103)\end{array}$ & $\begin{array}{c}-0.163 * * * \\
(-4.641)\end{array}$ \\
\hline Province-departure & & 30 provinces & 30 provinces & 30 provinces & 30 provinces \\
\hline
\end{tabular}


(Heilongjiang, omitted

category)

Constant

0.185

Observations

(0.396)

Pseudo R2

851,499

$(-4.917)$

(-3.284)

$-1.032 * *$

0.206

Notes: 1) Source: Authors' computations from subsample of 2005 sample survey;

2) z-statistics in parentheses; $* * * p<0.01, * * p<0.05, * p<0.1$

3) The definition about each kind of migration please see the text. 
Table 7 Estimated Multinomial logit for migration among adult persons originating in urban China in 2005

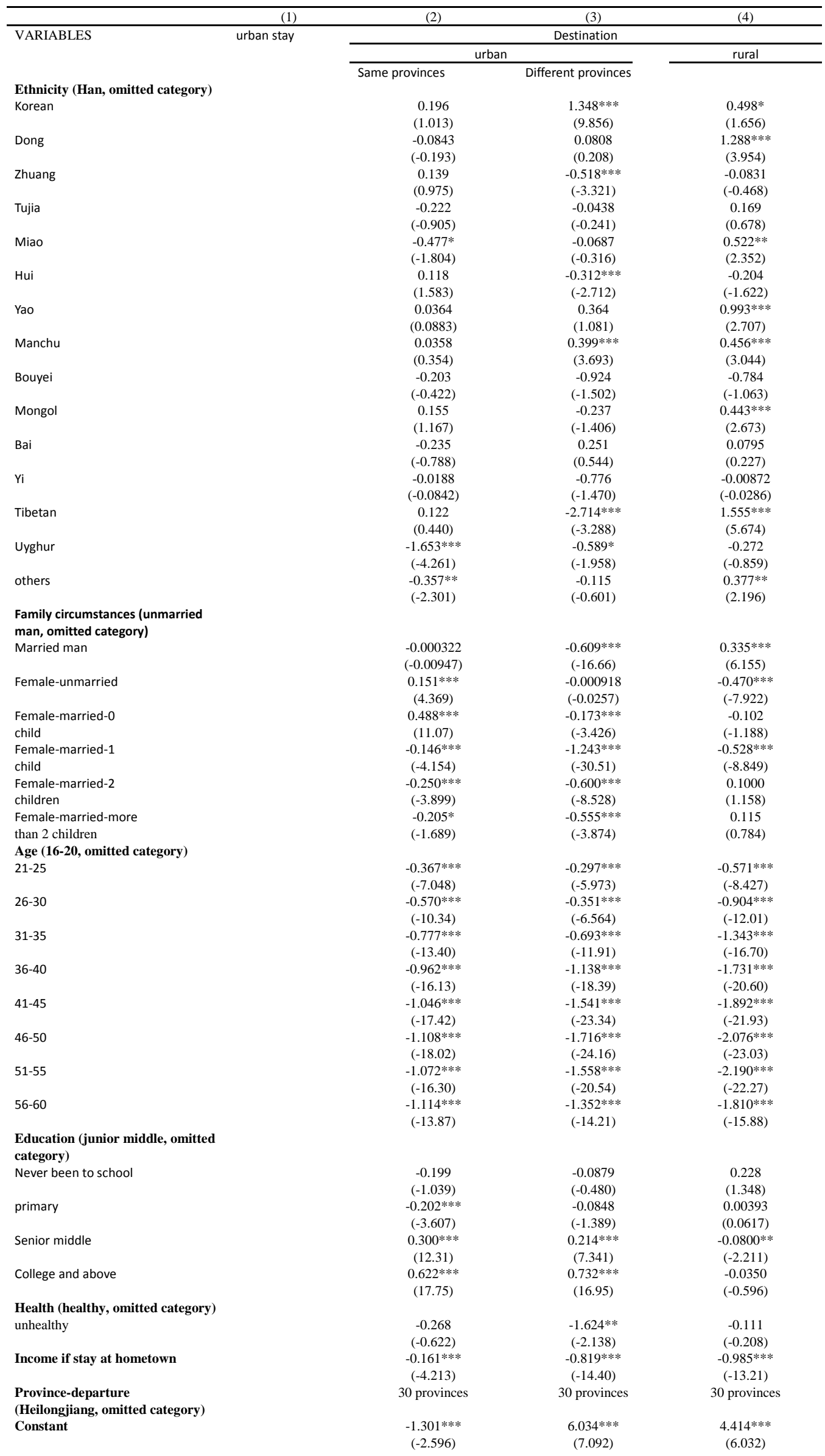


1) Source: Authors computations from subsample of 2005 sample survey;

2) $\quad \mathrm{z}$-statistics in parentheses; *** $\mathrm{p}<0.01, * * \mathrm{p}<0.05, * \mathrm{p}<0.1$;

3) The definition about each kind of migration please see M8. 
Figure 1 Migration intensities for 14 ethnic minorities and the majority in China in 2005 by kind of Hukou and destination

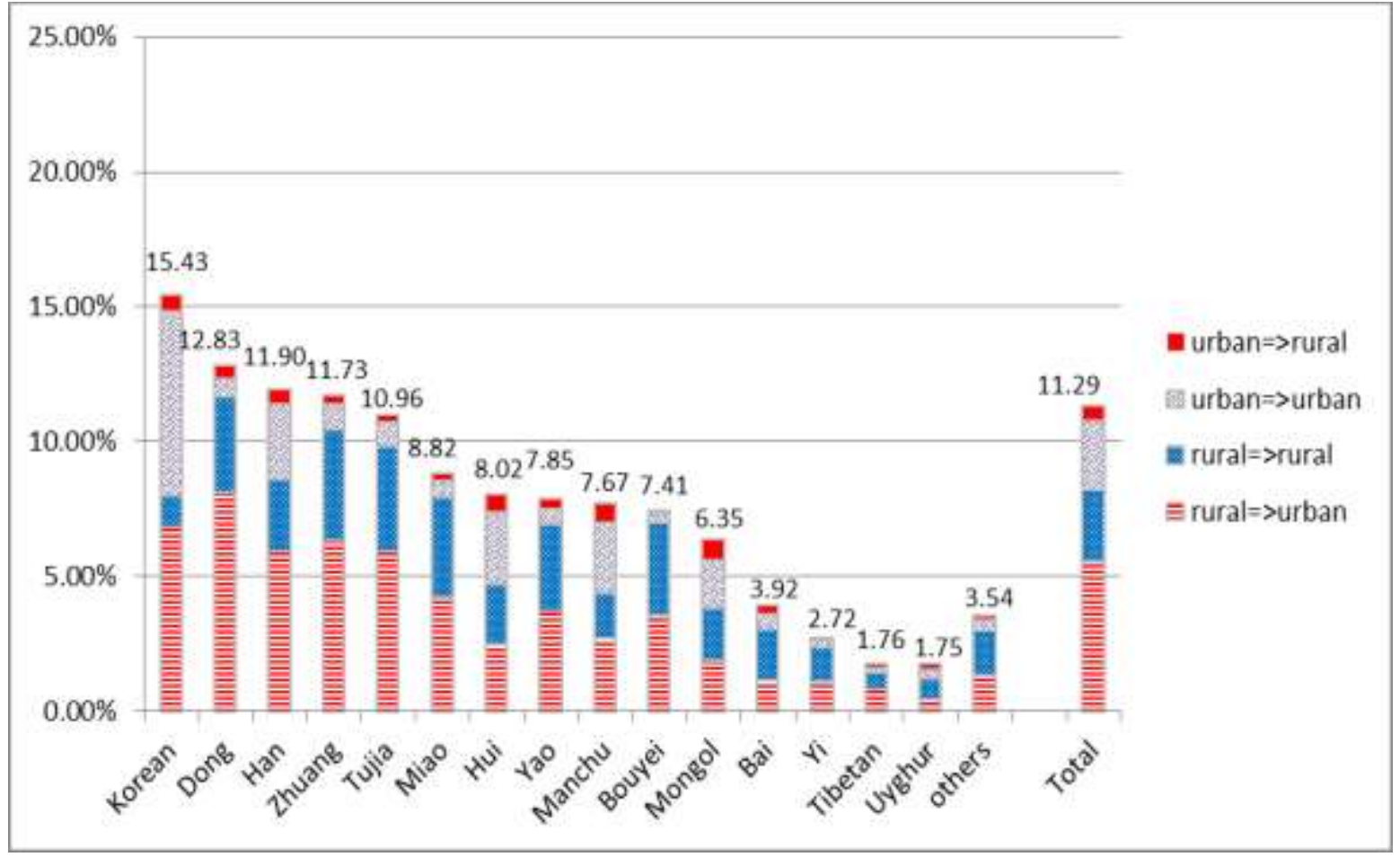

Note: 1) Source: Authors' computations from subsample of China's Inter-census Survey 2005;

2) When we calculate the total number of each ethnic minority population, the following observations are included: $16=<$ age $<=60$; not students;

3) Rural=>urban: the migrants who have a rural hukou and migrate to urban areas; rural $=>$ rural: the migrants who have a rural hukou and migrate to rural areas; urban=>urban: the migrants who have an urban hukou and migrate to urban areas; urban=>rural: the migrants who have an urban hukou and migrate to rural areas. 
Figure 2 Migration intensities for China's 31 provincial level units in 2005 by kind of Hukou and destination

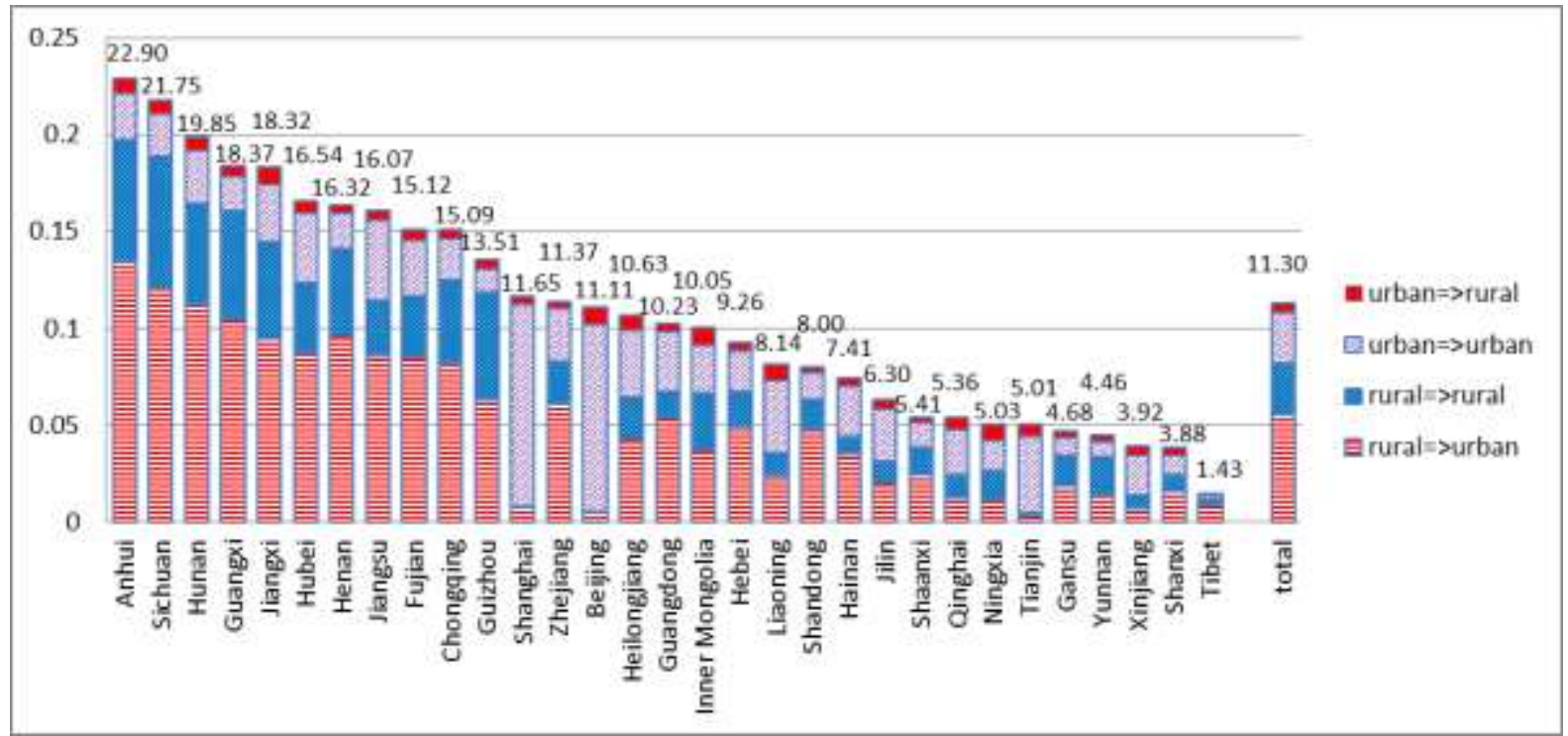

Note: 1) Source: Authors' computations from subsample of China's Inter-census Survey 2005;

2) When we calculate the number of people in each province, take Beijing for example, the following observations are included: the observations for which hukous are registered in Beijing, $16=<$ age $<=60$, not students;

3) Rural=>urban: the migrants who have a rural hukou and migrate to urban areas;

rural $=>$ rural: the migrants who have a rural hukou and migrate to rural areas;

urban=>urban: the migrants who have an urban hukou and migrate to urban areas;

urban $=>$ rural: the standard migrants who have an urban hukou and migrate to rural areas. 
Figure 3 Predicted probabilities of staying and four kinds of migrations for typical individuals having different ages and levels of education

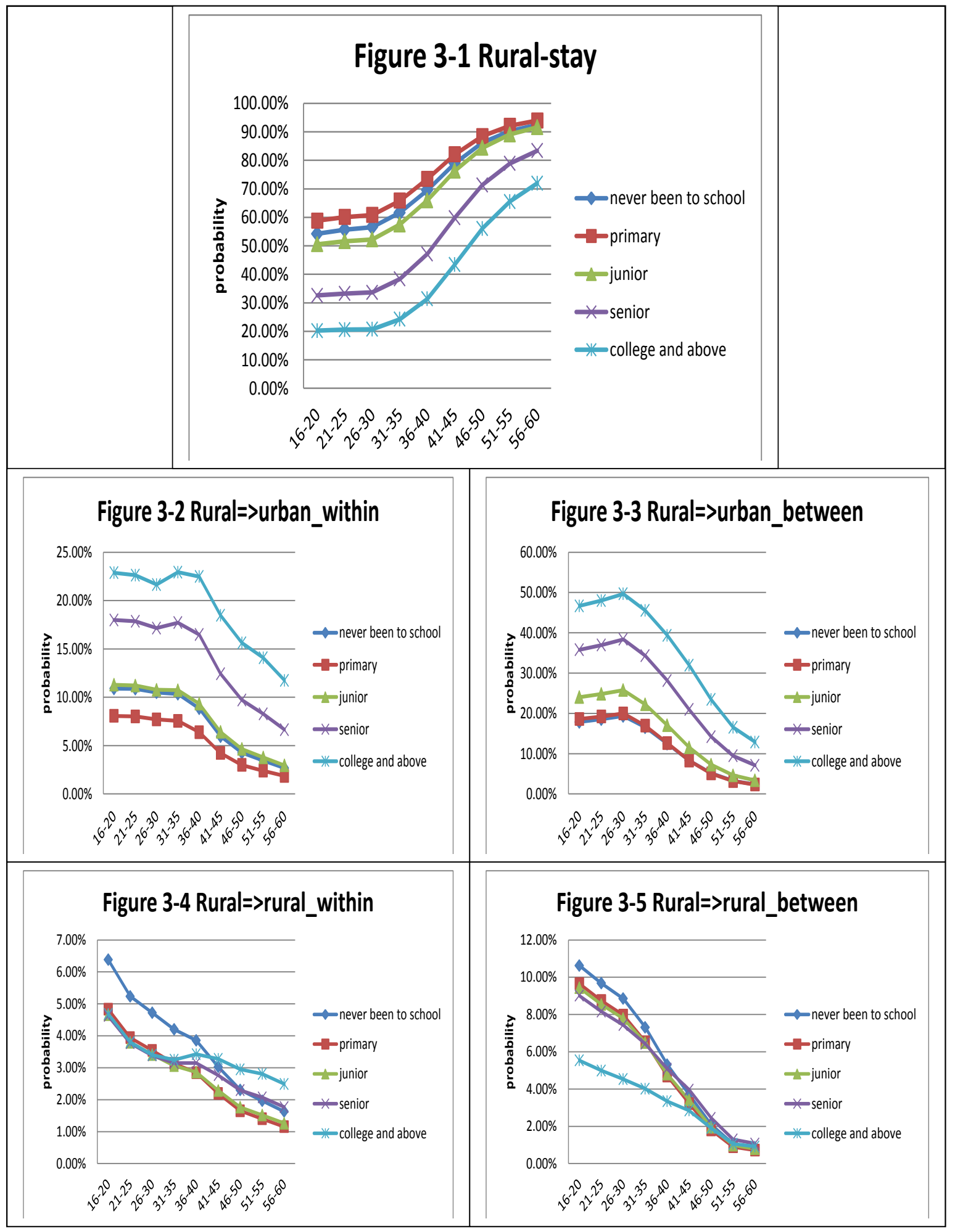

Source: Table 6;

Note: The typical individual who is of Han ethnicity, unmarried man, healthy, can earn mean income if remaining in hometown, lives in Heilongjiang. 


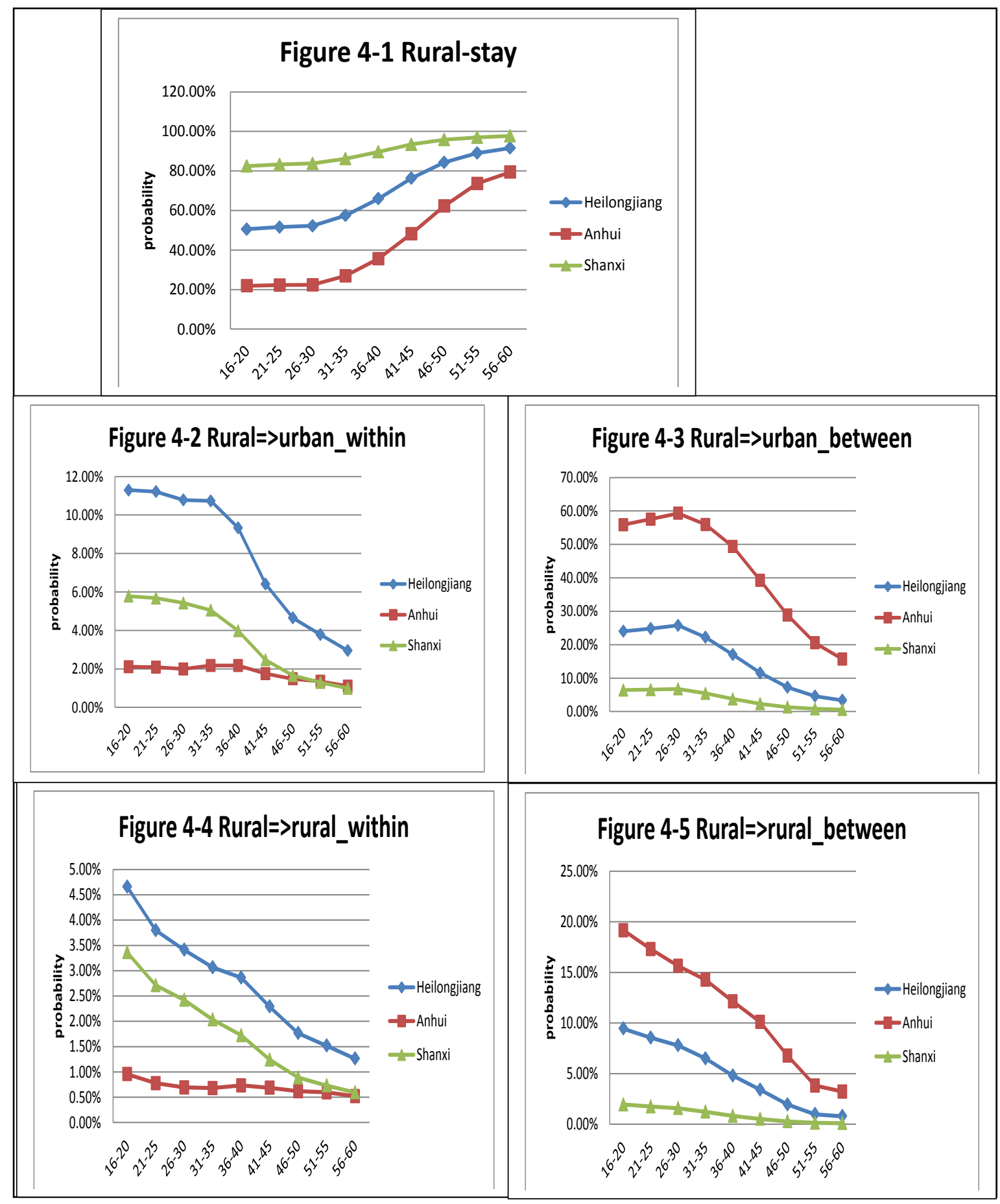

Source: Table 6;

Note: The typical individual who is of Han ethnicity, unmarried man, healthy, can earn mean income if remaining in hometown, whose education degree is junior middle school. 
Figure 5 Predicted probabilities of staying and four kinds of migrations for typical individuals living in a specific province belonging to the ethnic majority or to a specific ethnic minority

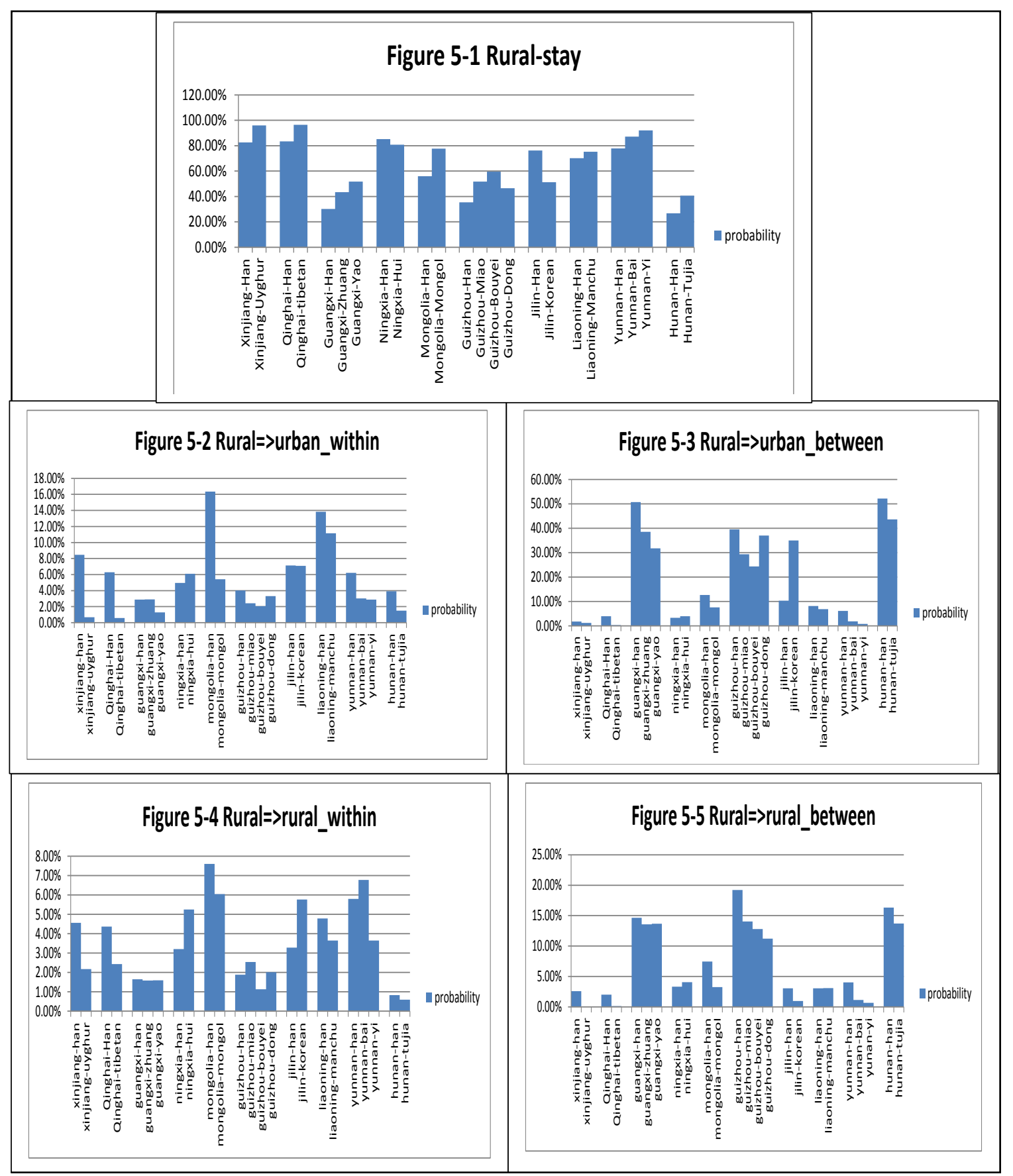

Source: Table 6.

Note : 1) The typical individual who is an unmarried man, healthy, can earn mean income if remaining in hometown, whose education degree is junior middle school and age is between 26 and 30 .

2) The provinces here studied are Xinjiang, Qinghai, Guangxi, Ningxia, Mongolia, Guizhou, Jilin, Liaoning, Yunnan, Hunan. 
${ }^{1}$ See for example the chapters in Iredal et al. (2003). Among China's 31 province level units' migration and ethnic differences in the labor market in Xinjiang autonomous regions has attracted attention by relatively many scholars: Hannum and Xie 1998; Zang 2008, 2010, 2011, 2012; Hooper and Webber 2009; Howell and Fan 2011; Wu and Song 2014. See also Abuduwaili and $\mathrm{Hu}$ (2010) who compared Uyghur migration to Urumchi and Xian. Studies of migration by minorities living in other parts of China are hard to find. Examples are Wu (2012) on Guizhou, Xiang (2012) on Koreans' current situation of social integration in three cities, and Tang (2006) who analyzed the characteristics of ethnic minority minorities migrants in a city of Gansu.

${ }^{2}$ According to Fan (2008, Chapter 3) there is overwhelming evidence that labor out-migration raises rural income and productivity. Remittances, in particular, have become an important means to improve economic well-being, to finance the economic and social activities of peasant households, and to alleviate rural poverty. On this see also Ma (2001) and Yang et al. (2005).

${ }^{3}$ On ethnic differences in the labour market in China see also Hasmath (2008) who studied the labour market in Beijing where the Manchu followed by the Hui are the two largest ethnic groups. Although ethnic minorities in Beijing outperform the majority when it comes to education, census data for 2000 shows that they are less likely to be found in high-wage occupational sectors. Hasmath (2011) carries the analysis further and suggests that social-network capital for the job searching, hiring and promotion are of importance. See also Hess (2009) who discusses tensions in a Guangdong factory between Han workers and Uyghur migrant workers recruited from southwest Xinjiang.

${ }^{4}$ Maurer-Fazio et al (2010) studied labor force participation rates in urban China using census data finding for example that in 2000 Hui, Korean, Mongolian and Uyghur women had lower labor force participation rates. Manchu women had participation rates similar to Han while Zhuang actually had higher rates.

${ }^{5}$ See also Gao (2008) as well as Vinod and Smyth (2013); the latter studies Korean minority persons living in Dalian and Yanji and suggests that the Koreans have the highest education attainment and occupation status of any of the ethnic minorities in China.

${ }^{6}$ One out of five persons from the sample was selected, in a way which appears to have been fully at random. When comparing variable values from our sub-sample with what has been reported in census 2000 and 2010, some differences became visible. For example there are more Tibetan minority persons in the sample than would be expected, compare Table 1 and Table 4.

${ }^{7}$ Chan (2012) Table 1 reports for the period 1982 to 2011 how different sources and definitions lead to different estimates of the number of migrants in China.

${ }^{8}$ For a study analyzing in detail how family circumstances affect migration among rural women in China, see Connelly et al (2012).

${ }^{9}$ Tong and Piotrowski (2012) shows using data from the 1997 to 2009 waves of the China Health and Nutrition Survey that migrants are positively selected on the basis of health and also that the relationship between health and migration had diminished over time.

${ }^{10}$ The variable monthly income includes earnings received in money but not asset income, transfer income or income from own production. 